Article

\title{
Impacts of an Innovative Residential Construction Method on Internal Conditions
}

\section{Roger Birchmore ${ }^{1}$ *, Andy Pivac $^{2}$ and Robert Tait ${ }^{2}$}

1 Department of Construction, Unitec Institute of Technology, P.O. Box 92025 Auckland, New Zealand

2 Department of Building Technology, Unitec Institute of Technology, P.O. Box 92025 Auckland, New Zealand; E-Mails: apivac@unitec.ac.nz (A.P.); rtait@unitec.ac.nz (R.T.)

* Author to whom correspondence should be addressed; E-Mail: rbirchmore@unitec.ac.nz; Tel.: +64-9-815-4321 (ext. 7372).

Academic Editor: George Baird

Received: 2 December 2014 / Accepted: 30 January 2015 / Published: 11 February 2015

\begin{abstract}
New Zealand houses are known for producing sub-optimal internal thermal conditions and unacceptably high internal moisture levels. These contribute to poor levels of health, mould and can coincide with the decay of structural timber frames. A proposed solution is to provide an alternative structure utilising plywood, a vapour check on the internal face of the timber frame and an additional air gap, followed by the internal lining. The internal vapour check is designed to prevent moisture vapour diffusion from inside into the frame and to permit moisture diffusion from outside through the structure to the internal environment. Two full scale houses had temperatures, dew points and humidity levels monitored in passive, unoccupied conditions. The test case house incorporated the innovative construction solution. The control house was of identical design and location, using standard construction practice. The calculated internal moisture content profile appeared to be unrelated to the external moisture content as expected, instead following the profile of the changing internal temperature. Whilst the innovative construction appeared to prevent moisture diffusion into the structure in winter and permit it inside in summer, this resulted in a generally higher internal relative humidity than the control house.
\end{abstract}

Keywords: housing; internal moisture; innovative construction, vapour check; airtightness 


\section{Introduction}

Mackintosh [1] summarises New Zealand's climate as:

"Warm subtropical in the far north to cool temperate climates in the far south, with severe alpine conditions in the mountainous areas. Mean annual temperatures range from $10^{\circ} \mathrm{C}$ in the south to $16{ }^{\circ} \mathrm{C}$ in the north of New Zealand. Most of New Zealand would have at least 2000 sunshine hours annually."

Auckland, New Zealand's largest centre of population, located in the north island experiences an average of 632 degree days (base $15.5^{\circ} \mathrm{C}$ ). In the alpine region in the South Island, Queenstown experiences an average of 2137 degree days to the same base [2].

This data does not describe harsh external conditions for much of the population but instances where combinations of low temperatures and high moisture levels lead to poor internal environments, in many parts or the country are documented widely by a number of authors [3-6]. The World Health Organisation [7] links poor internal conditions to a range of health problems that are also reported in New Zealand research. Reflecting the largely temperate nature of the climate, guidance from the Building Research Association of New Zealand (BRANZ) [8] is that vapour barriers are only a requirement in alpine regions or those with significant internal moisture generation linked with spa pools or other similar sources. Moisture in open roof spaces is also not considered to be a significant problem and New Zealand Building codes currently have no requirements for the ventilation of roof spaces. Since the publication of the guidance obviating the need for vapour barriers other changes to the Building Code have resulted in minimum insulations levels being raised. There are no requirements for the specific airtightness of buildings. In response to the challenges described, there has been research on solutions that tackle the problems of poor conditions and health directly or indirectly through improving the sustainability of homes [9-12]. This work has tended to focus on the thermal solutions and energy consumption aspects. Su $[13,14]$ extended this and researched the prevention of winter mould growth in occupied New Zealand houses employing primarily passive and active ventilation and thermal insulation prevention measures. Comparing the static and dynamic simulation methods de Groot [3] expanded further to explore in detail the impacts of moisture transfer through the envelope. He cautioned that the increase of thermal insulation without the consideration of interstitial moisture might move the visible mould problem to an invisible one. Simulating alternative retrofit solutions over a three year period in Auckland, he demonstrated that a vapour barrier was effective in preventing interstitial condensation occurring to levels that might encourage mould growth. Leardini and van Raamsdonk [15] added to the concerns of occupant health to include structural degradation. They also outline fears that increasing levels of thermal insulation increases chances of interstitial condensation. Their Wärmer und Feuchte instationär (WUFI) [16] software simulation of a timber framed house in Auckland, retrofitted with insulation, indicated a clear risk of interstitial conditions when examined over a three year period. This analysis also indicated the tendency for humid summertime conditions to drive moisture inside. The conventional vapour barrier approach risks trapping this moisture vapour into the structure as shown in Figure 1B. They propose that a solution is to provide a vapour check that prevents vapour transfer from moist inside conditions into the wall structure (Figure 1A,C) but also permits externally driven vapour to pass through the structure to the inside (Figure 1D). This vapour check additionally provides all the 
benefits of an airtight barrier, so whilst reducing the possibility of interstitial condensation, may exacerbate the challenge of increased internal moisture levels and its associated risks. De Groot and Leardini [17] identified a lack of information on the success of retrofit solutions and the general need to improve understanding of the impacts of combining insulation airtightness and humidity control. This paper outlines the early findings of a research project that moves research from desktop simulation to exploring the impact of a construction employing such a vapour check on unoccupied conditions in a real house.

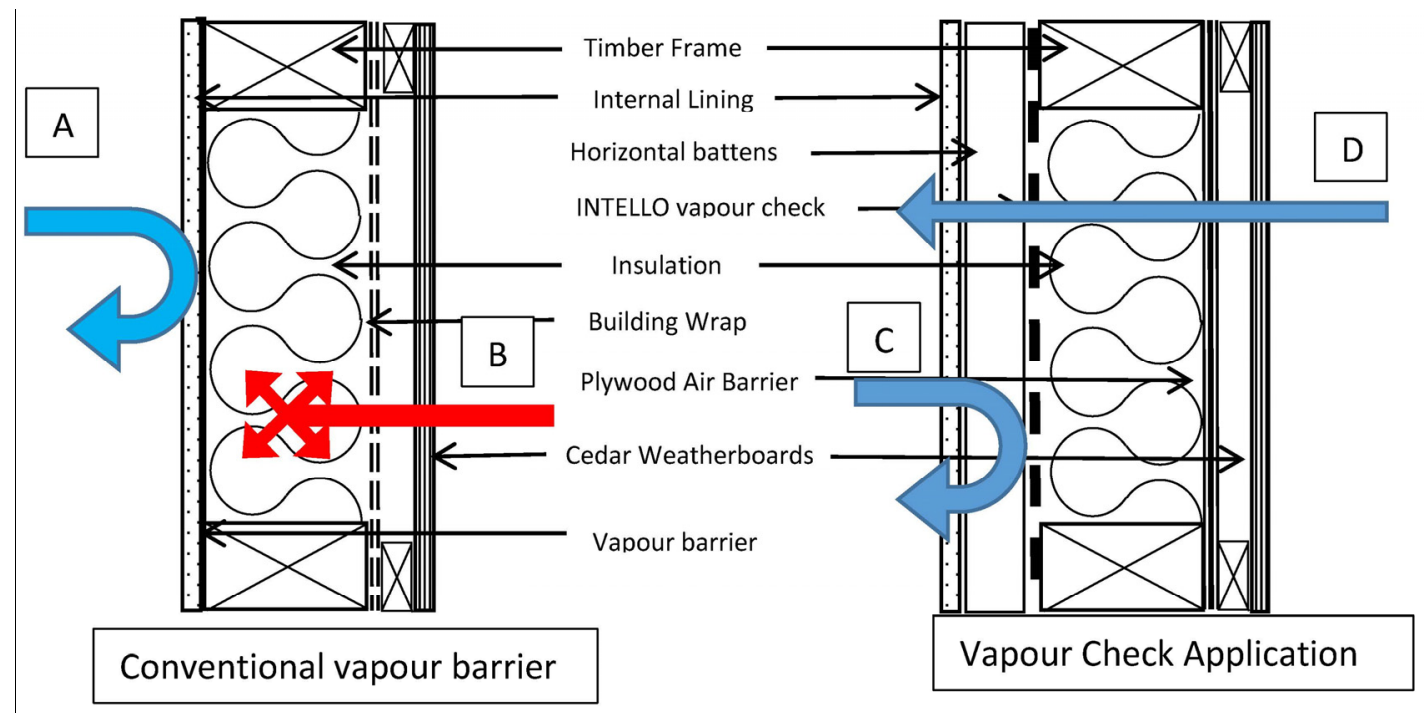

Figure 1. Moisture flows through the structure.

\section{Research Design and Methods}

The fundamental aim of this project is to allow comparison testing of individual or combinations of building materials and techniques that have the potential for improving the building performance of this standard New Zealand house type. In particular, this paper compares the use of a vapour check material not widely used in New Zealand, combined with a rigid air barrier, compared to conventional New Zealand construction methods. The particular focus is on impacts on the moisture levels and internal air temperatures. Initially, manual calculations employing the dew point method were conducted to investigate the likelihood of interstitial condensation occurring in the control house. Figure 2 shows the risk of condensation occurring in the structure $100 \mathrm{~mm}$ from the inside surface. Figure 3 shows how the vapour check removes this risk. This aligns with the more extensive analysis by Leardini and van Raamsdonk [15]. It was decided to employ the vapour check proposed in their work with a view to initially exploring its impact on the internal spatial conditions of the houses. [18,19] indicate the significant impact that occupants can have on the energy consumption and internal conditions of a space, quoting examples where variations were many times the base consumption figures. The two houses have therefore been tested in passive, unoccupied conditions to remove as many variables as possible. This data would provide the basis for predicting impacts of the construction methods on internal comfort conditions, risks of mould growth and also spatial heating and cooling energy use. This is the first stage of a project that will be followed with analysis of the construction method on the interstitial conditions. 


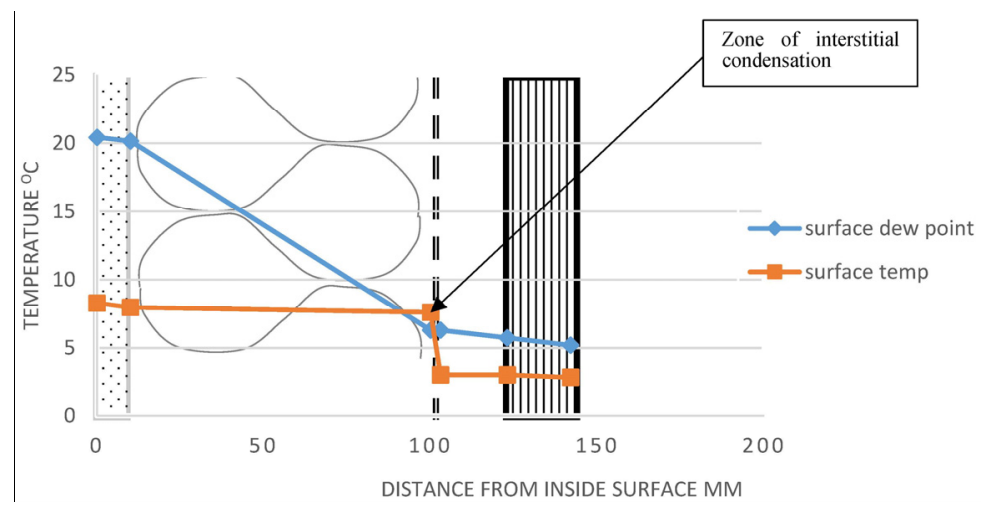

Figure 2. Interstitial condensation calculations in the control house.

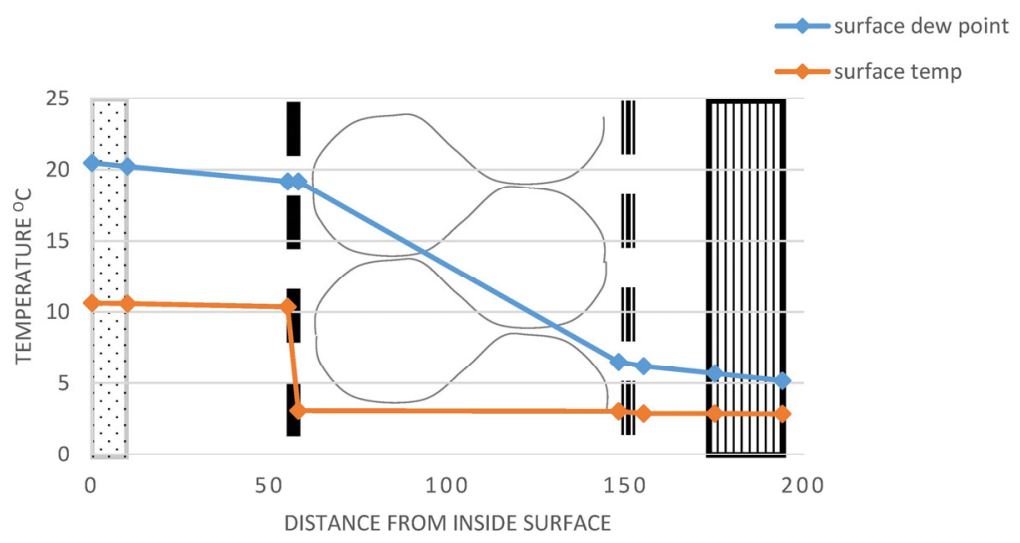

Figure 3. Interstitial condensation calculations in the test house.

\subsection{Control House}

The houses are single storied with three bedrooms and two bathrooms and are constructed as part of the Unitec carpentry programmes. The houses are completed by students to be relocated, and they are undecorated and without floor coverings or wall finishes. Electrical and plumbing fittings are installed but not connected. Figure 4 illustrates their overall nature.

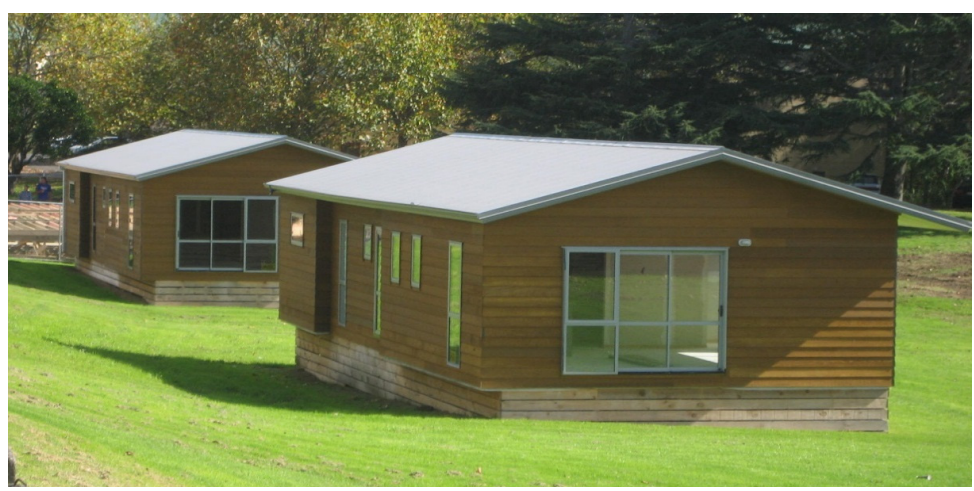

Figure 4. Control house (foreground) and test house.

Table 1 summarises the materials used in the construction of these houses. Overhangs on the north side of the house provide complete shading from direct solar gain through double glazing during the hottest periods of the summer months. These houses are similar in design and construction to thousands 
of houses found in suburban areas and provide an ideal basis for examining the potential for improvements to a common housing type.

Table 1. Construction details for the control and test houses.

\begin{tabular}{|c|c|}
\hline \multicolumn{2}{|c|}{ Common to Control House and Test House } \\
\hline \multicolumn{2}{|c|}{ Timber Frame on pile foundation } \\
\hline \multicolumn{2}{|c|}{ Sub floor cladding $150 \mathrm{~mm} \times 25 \mathrm{~mm}$ radiata pine boards with $20 \mathrm{~mm}$ gaps } \\
\hline \multicolumn{2}{|c|}{ Particle board, floor foil insulation draped between $190 \mathrm{~mm} \times 45 \mathrm{~mm}$ joists } \\
\hline \multicolumn{2}{|c|}{$140 \mathrm{~mm}$ polyester ceiling batts, $10 \mathrm{~mm}$ plasterboard } \\
\hline \multicolumn{2}{|c|}{ Double glazed windows } \\
\hline Control House & Test House \\
\hline Trussroof (radiata pine treated) Coloursteel & Trussroof (radiata pine treated) Coloursteel roofing on \\
\hline roofing on building paper & building paper, INTELLO wrap on bottom chord of trusses \\
\hline cedar weatherboard cladding, natural finish & cedar weatherboard cladding, natural finish \\
\hline $20 \mathrm{~mm}$ cavity battens & $20 \mathrm{~mm}$ cavity battens \\
\hline Building wrap & 7 mm Plywood \\
\hline $90 \mathrm{~mm} \times 45 \mathrm{~mm}$ radiata pine framing & $90 \mathrm{~mm} \times 45 \mathrm{~mm}$ radiata pine framing \\
\hline Polyester insulation & Polyester insulation \\
\hline- & INTELLO Vapour check \\
\hline- & $45 \mathrm{~mm} \times 45 \mathrm{~mm}$ battens \\
\hline $10 \mathrm{~mm}$ plasterboard & $10 \mathrm{~mm}$ plasterboard \\
\hline
\end{tabular}

Table 2 provides dimensional thermal and hygroscopic properties of relevant materials in the external envelopes. These are values associated with readily available material sizes to ensure the overall construction $R$-values exceed minimums stated in verification method H/VM1 [20], ensuring compliance with the New Zealand Building Code. Minimum $R$-values for this context are:

- Roof $2.9 \mathrm{~m}^{2} \mathrm{~K} / \mathrm{W}$

- Wall $1.9 \mathrm{~m}^{2} \mathrm{~K} / \mathrm{W}$

- Windows $0.26 \mathrm{~m}^{2} \mathrm{~K} / \mathrm{W}$

- Floor $\quad 1.3 \mathrm{~m}^{2} \mathrm{~K} / \mathrm{W}$

Table 2. Thermal and hygroscopic properties of materials.

\begin{tabular}{|c|c|c|c|c|c|}
\hline Material & Thickness $t$ & Conductivity $k$ & Resistance $R$ & $\begin{array}{c}\text { Vapour } \\
\text { Resistivity } r_{\mathbf{v}}\end{array}$ & $\begin{array}{c}\text { Vapour } \\
\text { Resistance } G \\
\end{array}$ \\
\hline- & $\mathbf{m m}$ & $\mathbf{W} / \mathbf{m K}$ & $\mathbf{m}^{2} \mathbf{K} / \mathbf{W}$ & MNs/gm & MNs/g \\
\hline External Walls & - & - & - & - & - \\
\hline Plasterboard & 10 & 0.22 & 0.05 & 60 & 0.6 \\
\hline Air gap (Test House) & 45 & - & 0.18 & - & 5 \\
\hline Vapour Check (Test House) & 3 & - & - & - & see Table 3 \\
\hline Insulation & 90 & 0.041 & 2.20 & 7 & 0.63 \\
\hline $\begin{array}{c}\text { Building Wrap (Control } \\
\text { House) }\end{array}$ & 3 & $\mathrm{n} / \mathrm{a}$ & $\mathrm{n} / \mathrm{a}$ & 2300 & 6.9 \\
\hline Plywood Air Barrier & 7 & 0.13 & 0.05 & - & 2.2 \\
\hline Ventilated Air Gap & 20 & - & 0.09 & - & - \\
\hline Cedar Weatherboard & 19 & 0.11 & 0.09 & - & 0.26 \\
\hline
\end{tabular}


Table 2. Cont.

\begin{tabular}{cccccc}
\hline Material & Thickness $\boldsymbol{t}$ & Conductivity $\boldsymbol{k}$ & Resistance $\boldsymbol{R}$ & $\begin{array}{c}\text { Vapour } \\
\text { Resistivity } \boldsymbol{r}_{\mathbf{v}}\end{array}$ & $\begin{array}{c}\text { Vapour } \\
\text { Resistance } \boldsymbol{G}\end{array}$ \\
\hline- & $\mathbf{m m}$ & $\mathbf{W} / \mathbf{m K}$ & $\mathbf{m}^{2} \mathbf{K} / \mathbf{W}$ & $\mathbf{M N s} / \mathbf{g m}$ & $\mathbf{M N s / g}$ \\
\hline Roof Structure & - & - & - & - & - \\
\hline Plasterboard & 10 & 0.22 & 0.05 & 60 & 0.6 \\
Air gap (Test House) & 45 & - & 0.18 & - & 5 \\
Vapour Check (Test House) & 3 & - & - & - & see Table 3 \\
Air Gap & 300 & - & 0.16 & - & 5 \\
Building Wrap & 3 & - & - & 2300 & 6.9 \\
Profiled Sheet Steel Roof & 4 & - & - & - & 2000 \\
\hline
\end{tabular}

\subsection{Test House}

The test house was constructed one year later than the control house and modifications incorporated the use of the INTELLO vapour check proposed by Leardini and van Raamsdonk [15]. In addition modifications were made were to replace the building paper with $7 \mathrm{~mm}$ thick plywood barrier treated to H3.2 CCA (Copper Chrome Arsenate) in accordance with AS/NZ 1604.3 [21] to meet AS/NZS 2269.0 [22]. Vertical sheet joints were sealed with flashing tape. This feature was felt to have significant potential as an alternative that provided the functions of bracing and rigid air barrier in a single element that offered enhanced seismic resistance. This had potential for use in the rebuild of houses since the Christchurch earthquakes. The vapour check was placed on the internal surfaces of external walls and ceilings. A $45 \mathrm{~mm}$ cavity batten was then added before fixing of the plasterboard. Details are shown in Figures 5 and 6. Ceiling insulation was placed directly on top of the ceiling material in the control house and on top of the INTELLO vapour check in the control house. In both houses the roof space that resulted was an uninsulated cavity. The INTELLO vapour check is intended to have two functions. The first is to control the passage of vapour through the timber to the structure. This minimises the chances of charging the frame with moisture that could then condense during cold spells, eventually resulting in the rotting of the frame. Its high level of resistance shown in Table 3 prevents vapour generated internally from passing into the structure in winter. The low level of resistance in the opposite direction permits the vapour to pass from high humidity conditions present in summer time though the structure to the inside. This again prevents the possible accumulation of moisture in the frame for future condensation. The second function is for the INTELLO vapour check to act as an additional barrier to infiltration through the fabric of the building. The minimisation of infiltration is proposed to be an important contributor to reducing unplanned heat loss and moisture ingress. The additional air gap between the INTELLO and the internal plasterboard lining provides a route for internal services to circulate with minimal penetrations through the INTELLO. 


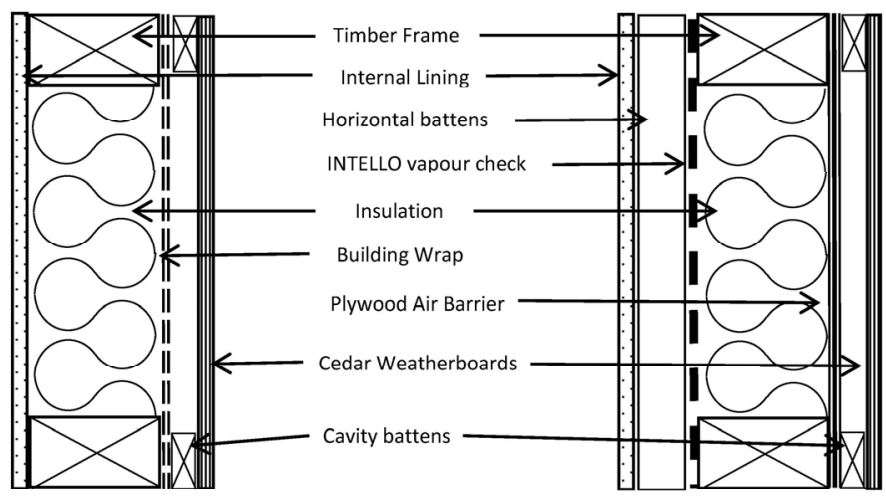

Control House

Test House

Figure 5. Construction detail—external walls.

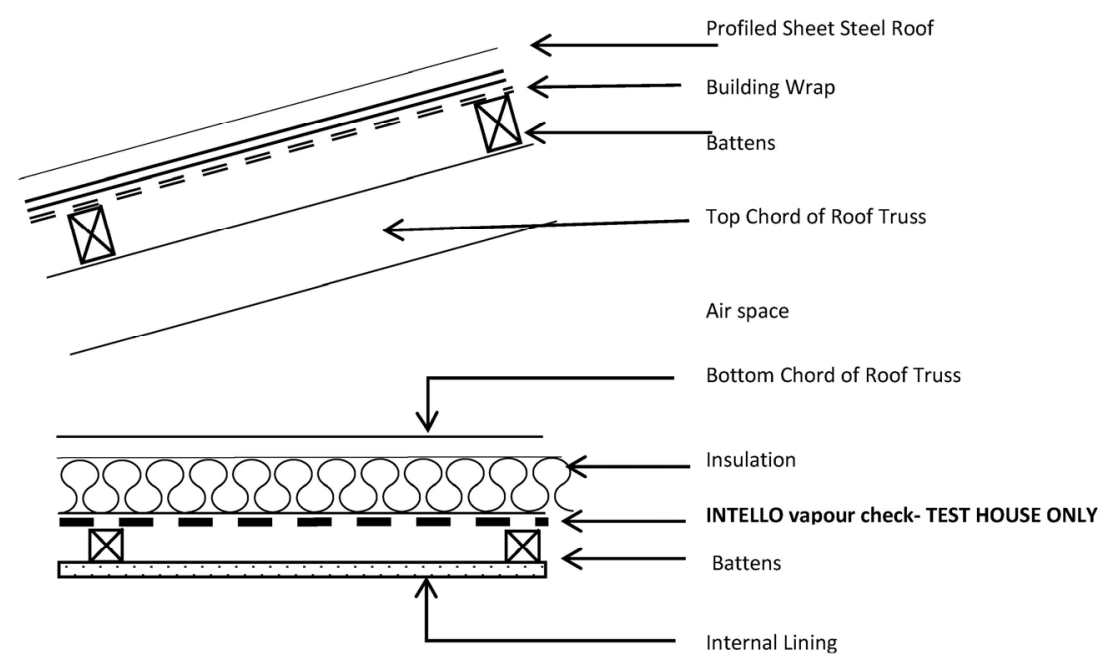

Figure 6. Construction detail—roof.

Table 3. Vapour diffusion resistance of the INTELLO membrane [23].

\begin{tabular}{ccc}
\hline Testing Conditions & \multicolumn{2}{c}{ Vapour Diffusion Resistance (MNs/g) } \\
\hline Average Ambient Humidity & $20 \%$ & $85 \%$ \\
Direction of Diffusion Flow & Out towards the air barrier & Inwards towards the air barrier \\
INTELLO & 125 & 1.25 \\
\hline
\end{tabular}

\subsection{Site}

The site is on the Unitec Institute of Technology campus in Mt Albert Auckland. The site is relatively exposed with an open grassed area to the northwest. Surrounding buildings are reasonably distant to the south, north and east. Behind the houses to the southeast is a hilly incline and the student building yard. The houses are located with identical orientations but separated to avoid mutual shading.

\subsection{Monitoring Process}

Temperature sensors have been set up to sample the internal air temperature at hourly intervals. Sensors used are Lascar EL-USB-2 Humidity and Temperature USB data loggers. These measure and 
store relative humidity $(\mathrm{RH})$, dew point (DP) and dry bulb air temperature readings (DB) over $0 \% \mathrm{RH}$ to $100 \% \mathrm{RH}$ and $-35{ }^{\circ} \mathrm{C}$ to $+80{ }^{\circ} \mathrm{C}$ measurement ranges. Sensors were located identically in the two houses to align with practice outlined by Barley et al. [24] at a height of $1500 \mathrm{~mm}$ above ground level suspended from the ceiling by builders twine. Sensor layout is given in Figure 7. In order to check the appropriate test location for the sensor, a second sensor was located at the edge of the room to check initial operation and determine the degree of variability experienced across each space. It was found that the average variation between measurements from the centre of the room and from the edge of the room vary by an average of $0.2^{\circ} \mathrm{C}$ over the 168 hourly measurements, with the maximum variation less than $0.5^{\circ} \mathrm{C}$. This is well within the accuracy stated for the sensors which is stated to be $\pm 0.5{ }^{\circ} \mathrm{C}$ [25] and indicates that a single measurement in the chosen position is representative of the overall room conditions. Dew point measurements have been used as this single figure provides an indicator of absolute moisture content. Localised weather data is measured at a weather station indicated in Figure 8 . They are monitored in a passive, unoccupied condition.

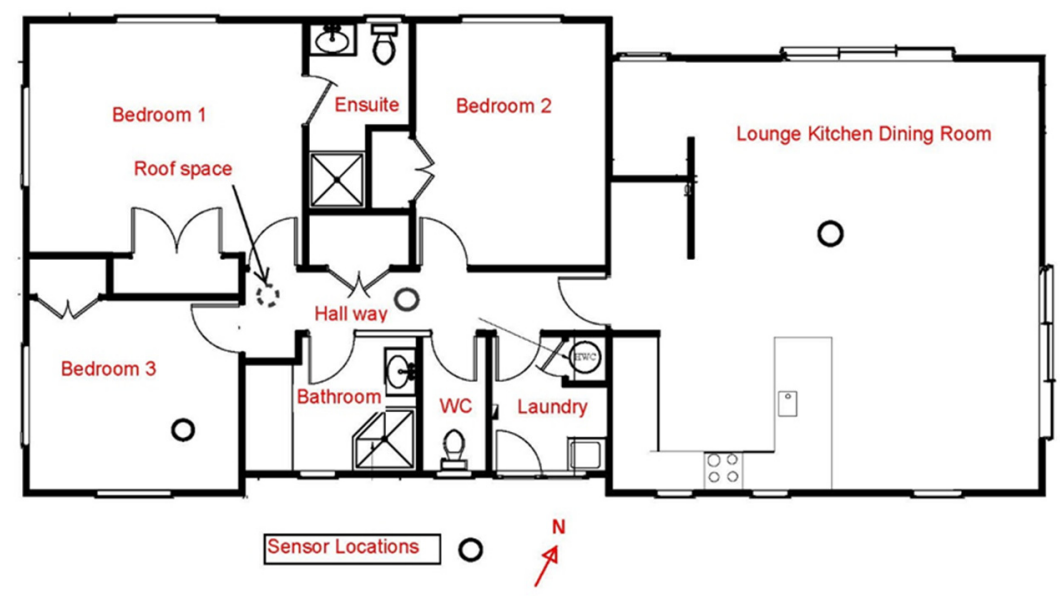

Figure 7. House plan with sensor locations.

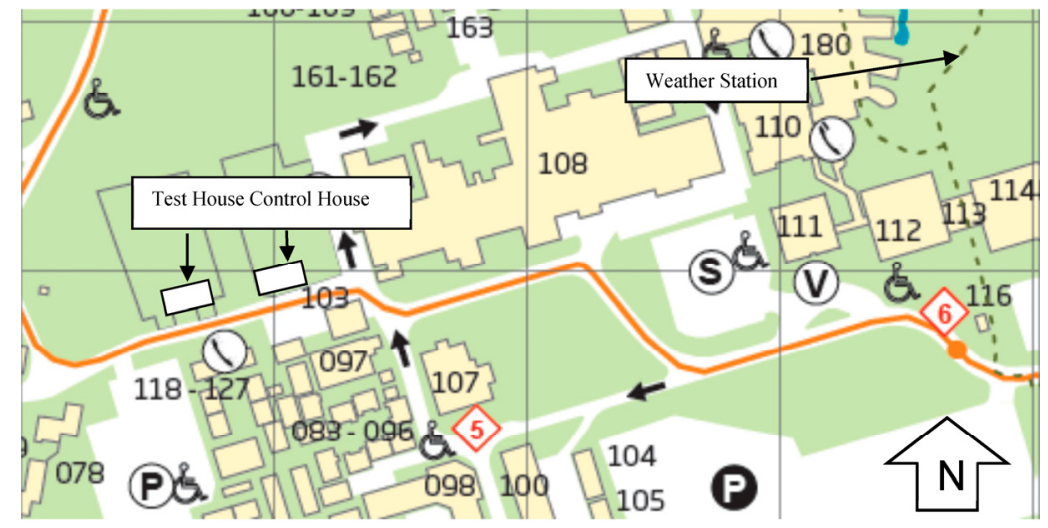

Figure 8. House and weather station location details.

\subsection{Air Tightness}

Both houses were tested for air tightness using the standard blower door test following European standard EN 13829:2000 [26]. Openings associated with extract ventilation and unconnected waste pipes were sealed for air pressure testing and for subsequent monitoring of air temperature, dew point and 
relative humidity. Table 4 shows the air changes per hour of the whole house volume under the standard test conditions of $50 \mathrm{~Pa}$ pressurisation and $50 \mathrm{~Pa}$ depressurisation. It indicates that the test house has an air leakage rate of less than a third of the control house. The control house sits just outside the airtight classification for New Zealand houses which peaks at an airtightness of $5 \mathrm{ac} / \mathrm{h}$ [27]. The test house is comfortably in the airtight classification but is still well above the requirements of the Passive House Institute [28].

Table 4. Results of airtightness testing.

\begin{tabular}{ccc}
\hline Testing Conditions & Control House (ac/h) & Test House (ac/h) \\
\hline Depressurisation & 6.58 & 1.92 \\
Pressurisation & 6.93 & 2.10 \\
Average & 6.75 & 2.01 \\
\hline
\end{tabular}

\subsection{Rooms Being Analysed}

The rooms chosen for analysis in this paper were the lounge kitchen dining room, bedroom 3, hall and the roofspace. Floor and wall areas are shown in Table 5. The lounge kitchen dining room is the largest space in the house and is has external walls on the South, East and North Face with glazing in each with a window to wall ratio of $29 \%$. Its inclusion of the kitchen also examines a space where occupancy may generate significant additional internal moisture. Bedroom 3 is on the opposite, coldest corner of the house receiving minimal solar gain. With a window to wall ratio of $41 \%$ the hall is internal with the exception of its floor and ceiling. The roofspace provides data on the external side of the vapour check in the test house and the external side of the insulation in both houses.

Table 5. Details of rooms being analysed.

\begin{tabular}{ccc}
\hline Room & Floor Area $\left(\mathbf{m}^{\mathbf{2}}\right)$ & Net External Wall Area $\left(\mathbf{m}^{\mathbf{2}}\right)$ \\
\hline Lounge Kitchen Dining room & 46.4 & 33.6 \\
Bedroom 3 & 9.8 & 11.07 \\
Hall & 5.6 & Nil \\
Roofspace & 120.5 & Nil \\
\hline
\end{tabular}

\section{Results and Discussion}

\subsection{Seasonal Data}

The means of dry bulb (DB) and dew point temperatures, (DP) measured at hourly intervals for the winter and summer seasons are summarised for each building in Figure 9. The summer season is defined as 1 December-28 February, spring as 1 March-31 May, winter as 1 June-31 August and spring as 1 September-30 November. The data indicates that as the mean temperatures drop towards winter and as expected rise up again in spring. Also as expected, the range of temperatures in the roofspace exceed those in occupied spaces indicating the smoothing effect of in wall and under floor insulation. The trend and interrelationship holds for all three internal spaces suggesting that the airspace in each room within each house is reasonably homogenous and that orientation and wall to window ratios have a small effect on mean temperatures. Absolute moisture content and dry bulb temperature are not parameters that are 
inherently connected. As the buildings have no internal moisture generation it was expected that absolute moisture contents, represented by the dew point temperature levels would follow external moisture readings. Figure 9 indicates that in fact they seem to follow the internal dry bulb readings. The detail of a few sample days in Figures 10 and 11 re-enforces this and indicates little or no connection between internal and external dew point temperatures.

\section{Mean seasonal temperatures and dew points}

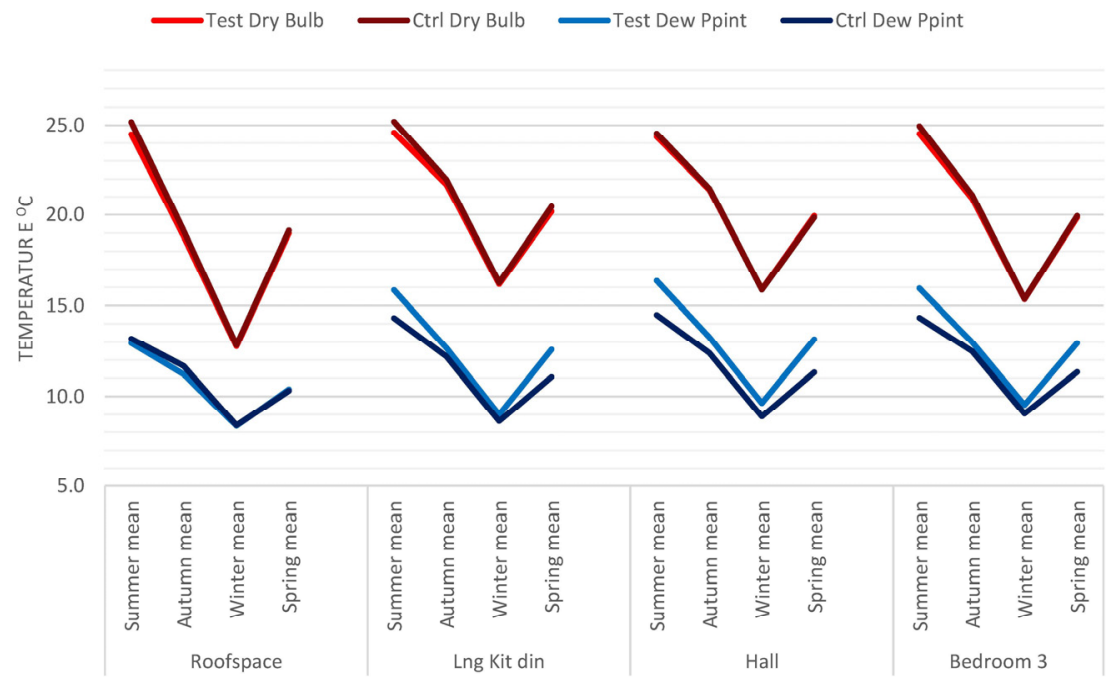

Figure 9. Comparison of space temperature and dew point seasonal means.

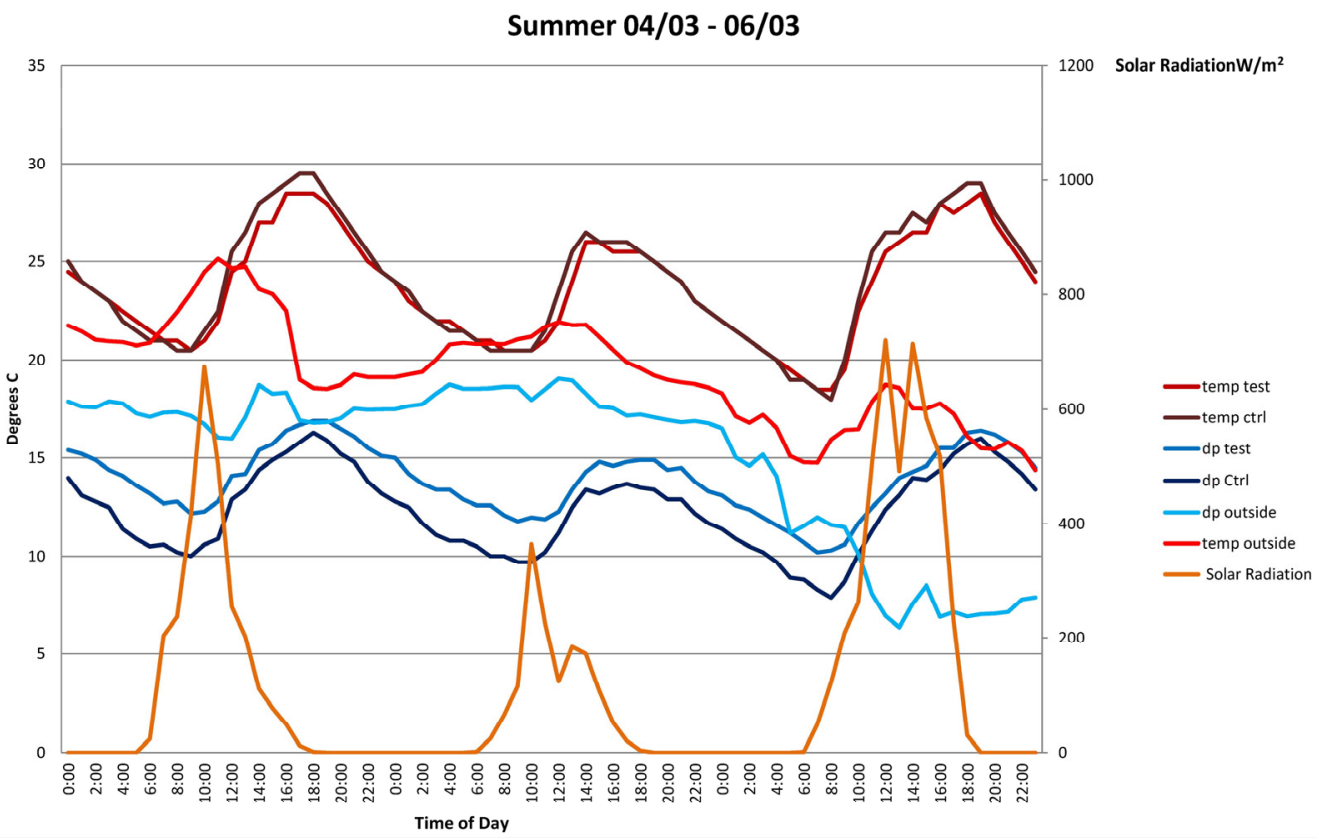

Figure 10. Dry bulb and dew point comparisons for the lounge kitchen dining room with external summer conditions. 


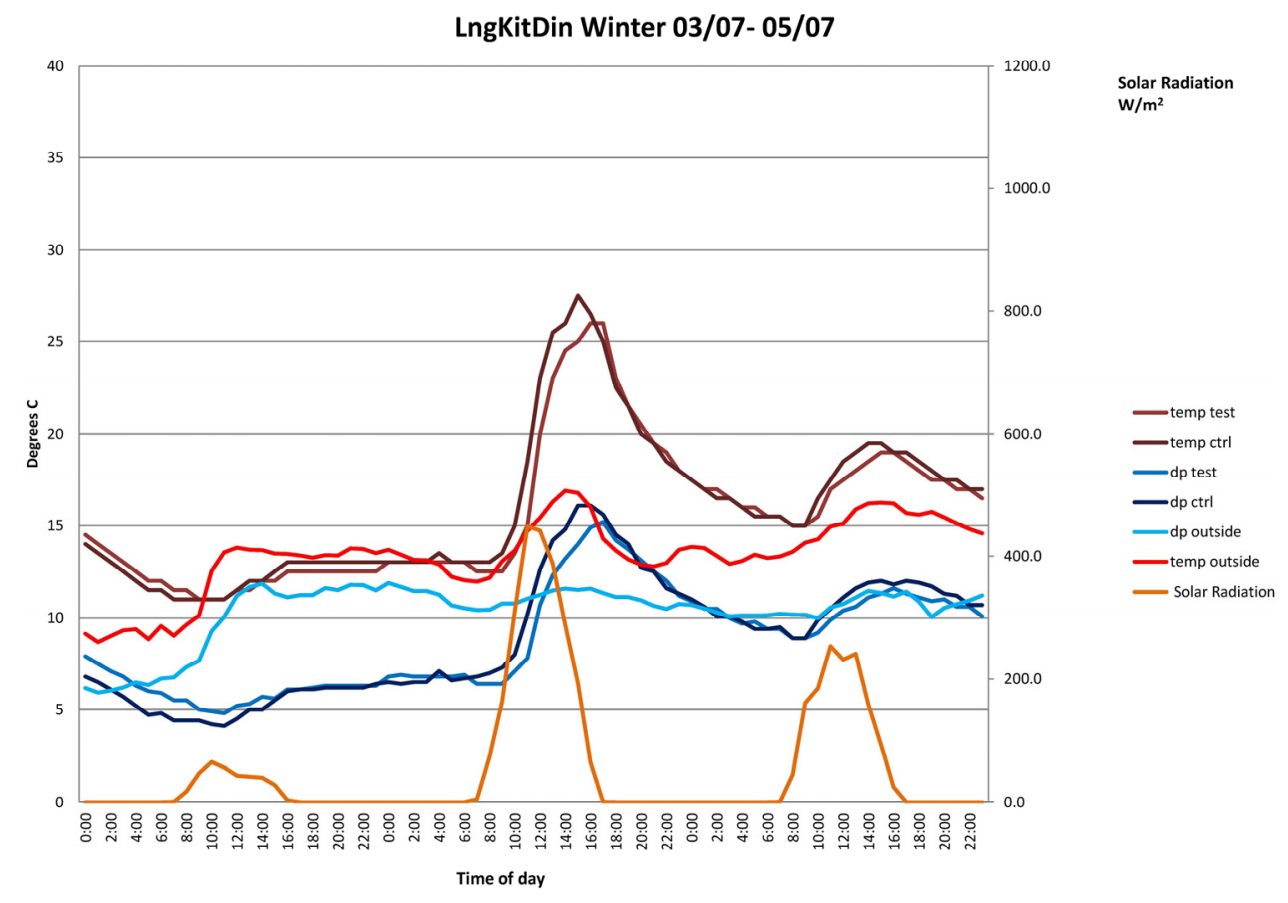

Figure 11. Temperatures and dew point comparisons for the lounge kitchen dining room with external winter conditions.

The significance of the differences between seasonal measures of control and test dry bulb temperatures and between control and test dew point temperatures were calculated using a two tailed $T$-test. Calculations were completed on two spaces, the roofspace and the lounge kitchen dining room being the most different spaces. Calculations were completed on seasonal means using an alpha of 0.05 with a hypothesis that the difference between two population means would be zero. $P$ scores are quoted to four significant figures.

Scores where $p \geq 0.05$ indicates that the hypothesis is correct and that there is no significant difference between the populations. Scores where $p \leq 0.05$ indicates the hypothesis is incorrect and that there is a significant difference between the populations. Table 6 shows that in all spaces with the exception of the roofspace during winter and for dry bulb temperatures in spring the difference between the test and control house was statistically significant with a confidence of $95 \%$.

Table 6. Summary of statistical significance of differences between control and test houses.

\begin{tabular}{cccc}
\hline Season & Space & Dry Bulb & Dew Point \\
\hline \multirow{2}{*}{ Summer } & - & $\boldsymbol{p}$ & $\boldsymbol{p}$ \\
& LoungKitDin & 0 & 0 \\
& Roofspace & 0 & 0 \\
\hline \multirow{2}{*}{ Autumn } & LoungKitDin & 0 & 0 \\
& Roofspace & 0 & 0 \\
\hline \multirow{2}{*}{ Winter } & LoungKitDin & 0 & 0 \\
& Roofspace & 0.1007 & 0.3745 \\
\hline \multirow{2}{*}{ Spring } & LoungKitDin & 0 & 0 \\
& Roofspace & 0 & 0.0263 \\
\hline
\end{tabular}




\subsection{Detailed Results of Selected Days}

\subsubsection{Summer}

The detailed results of a few days in each season are shown in Figures 10-13. They have been chosen to illustrate the apparent strong influence of solar gain on internal conditions. This indicates that the internal dry bulb temperatures follow the cyclical pattern of the external solar gain. The periods of the two cycles appear identical but with the dry bulb lagging between four and $6 \mathrm{~h}$. The internal dew point also follows with the same period but with slightly reduced amplitudes. There is a very weak connection if any, with the dew point of the external air. As there were no occupant generated sources of internal moisture, the changing dew points over a daily cycle could be resulting from residual construction moisture. As the temperature rises, moisture still present in the construction evaporates into the air. As it cools it is re-absorbed into the structure. Whilst the test house vapour check is designed to reduce this, the floors of both houses are exposed particle board and the unpainted gypsum board will have some absorption capacity.

Bed 3, Hall Roofspace Summer 04/03 - 06/03

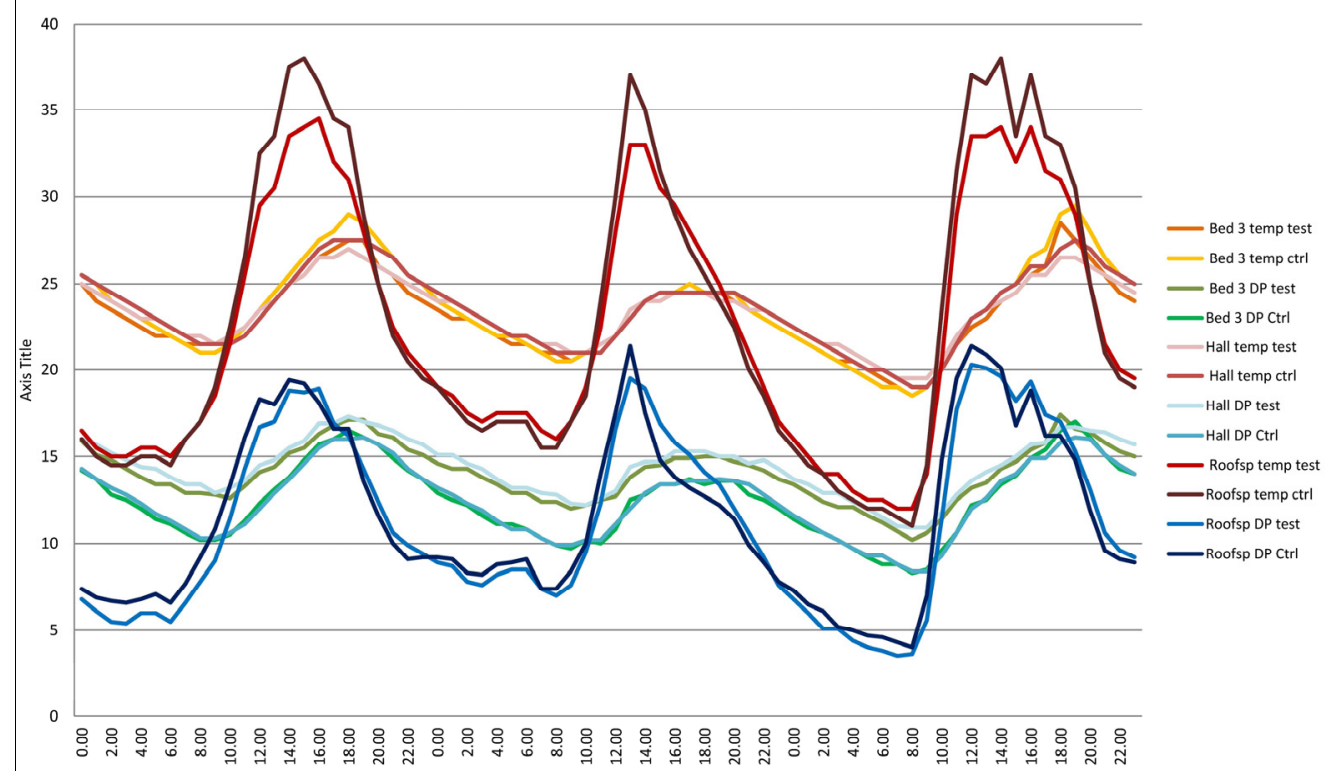

Figure 12. Dry bulb temperatures and dew point comparisons for the bedroom 3 hall and roofspace with external summer conditions.

Figure 12 shows the performance for three other spaces during the same period. The external conditions are the same as in Figure 10 but have been removed for clarity. Reflecting the seasonal means in Figure 9, the roofspace exhibits a wider range of variations than other internal spaces. The dry bulb and dew point temperatures in the bedroom 3 and hall cluster close together within similar ranges and cycle to those of the lounge kitchen dining room. This demonstrates that the seasonal homogeneity is reflected on a daily cycle. The reduction of extreme internal temperatures by thermal insulation in the roofspace is also very clear on this daily cycle. The four to $6 \mathrm{~h}$ lag between peak external temperature and internal temperature observed in the lounge kitchen dining room remains for other internal spaces. This is reduced to two hours for the roofspace. The reduction in lag is expected as the temperature is being 
measured on the external side of the insulation. Differences between dry bulb temperatures in the control house and the test house are small, being largest at extremes of conditions and very small between. Differences between the dew point readings in the houses appear more significant and more evenly spread over the daily cycle.

\subsubsection{Winter}

The data in Figure 11, Illustrates the strong link between solar gain, internal dry bulb and internal dewpoint temperatures where the solar gain on the second day leads and influences the plots of other parameters. Notably the thermal lag in both houses has reduced to approximately $2 \mathrm{~h}$.

Figure 13 reflects parallels with Figure 12 but with lower temperature levels associated with the winter season. The clustering of the graphs continues to support the homogeneity of the internal spaces. The roofspace extremes are reduced. Time lags have also reduced to a maximum of two $h$ and minimums of zero. Differences between control and test house dry bulb temperatures and dew points are very small especially on the first day with low solar radiation.

Moisture Contents, in $\mathrm{kg}$ of moisture per $\mathrm{kg}$ of dry air, can be read from a Psychrometric chart for given dew points. Using the mean density of the air and the space volume, the volume of moisture being evaporated and re-absorbed on a daily cycle can be estimated. 1 December was chosen as the day with the maximum daily change in dew point temperature and Table 7 indicates the result as $0.52 \mathrm{~L}$.

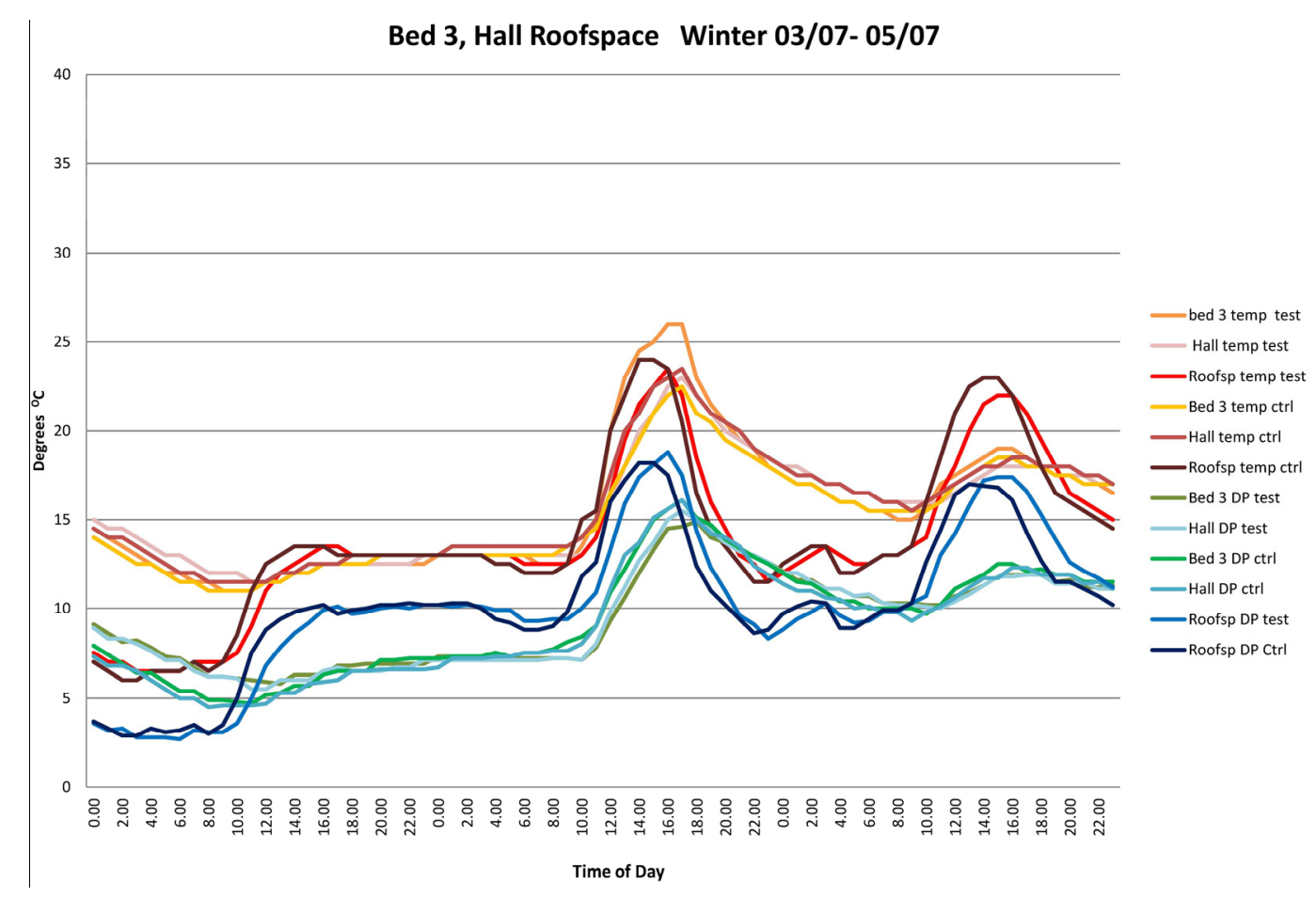

Figure 13. Dry bulb temperatures and dew point comparisons for the bedroom 3 hall and roofspace with external winter conditions. 
Table 7. Data for estimation of the moisture volume being evaporated and re-absorbed.

\begin{tabular}{cccc}
\hline \multicolumn{4}{c}{ Summer 1st Dec } \\
\hline Dry Bulb $\left({ }^{\circ} \mathbf{C}\right)$ & Dew Point $\left({ }^{\circ} \mathbf{C}\right)$ & Density $\left(\mathbf{k g} / \mathbf{m}^{3}\right)$ & Moisture Content $(\mathbf{k g} / \mathbf{k g})$ \\
\hline Max 25.5 & 15.4 & 1.163 & 0.0109 \\
Min 15.5 & 8.6 & 1.211 & 0.0069 \\
Difference & 6.8 & - & 0.004 \\
Mean density $\left(\mathrm{kg} / \mathrm{m}^{3}\right)$ & - & 1.187 & - \\
Space volume $\left(\mathrm{m}^{3}\right)$ & 108.54 & - & - \\
Space mass $(\mathrm{kg})$ & 128.809 & - & - \\
Moisture mass $(\mathrm{kg})$ & 0.52 & - & - \\
Moisture volume $(\mathrm{L})$ & 0.52 & - & - \\
\hline
\end{tabular}

\section{Conclusions}

The internal seasonal spatial data in Figure 9 along with the statistical analysis supports the expected performance of the test house structure regarding internal moisture levels. The summer season trends are reinforced by the daily analysis in Figure 10. In winter, higher internal dew points in the test house compared to the control house suggest that internal vapour is held within the occupied space and is not being permitted to enter the structure. The risk of interstitial condensation should therefore be reduced. In summer, higher internal dew points in the test house compared to the control house suggest that vapour is being allowed to pass through the structure to the inside. This prevents the moisture getting trapped within the timber frame, reducing the potential to cause interstitial condensation when the climate permits. The roofspace data supports this further. As the readings are on the external side of the vapour check, vapour passing through the check in summer should result in lower dew point temperatures within the control house roofspace compared to the test house. Figure 10 indicates this. They should also be lower in winter but this is not as evident when looking at seasonal means or the test of significance, but the daily analysis in Figure 12 does support this. Overall this differentiates the performance of the vapour check from a conventional vapour barrier which would trap the moisture within the timber structure, preventing it from entering the occupied space.

Compared to the control house, the test house offered improved thermal resistance from the additional sealed air gap and significantly reduced infiltration due to the vapour check properties. It was felt that this would result in warmer test house conditions in winter and cooler conditions in summer. Overall differences are not large however. Small differences between the average dry bulb temperatures over the winter and spring seasons between the control and test Houses suggest that the different properties are having a small effect on unoccupied thermal conditions. Figure 11 shows that on cloudy winter days the difference between internal and external temperatures was minimal and so differences between control and test houses could also be very small. However on sunny winter days, internal temperatures rose nearly ten degrees higher than outside. Under these winter conditions the test house was actually slightly cooler than the control house. As the test house infiltration rate was one third of the control house rate, this suggests that the heat losses due to infiltration through the closed structure in an unoccupied condition might be much smaller than anticipated or are not being prevented by increased airtightness of the envelope. 
The calculated daily variation of $0.52 \mathrm{~L}$ of water is a small proportion of the possible moisture generation in a house. TenWolde and Pilon [29] suggest that a family of four would produce up to $15 \mathrm{~L}$ per day. However, $0.52 \mathrm{~L}$ represents the amount of moisture left to be absorbed by the air. The moisture absorptive properties on internal linings, quantified by Mitamura, Rode and Schultz [30] and termed moisture buffering, could account for a larger volume of daily moisture change in the unoccupied condition.

The tendency of the vapour check to produce slightly higher internal dew points emphasises the need to combine this type of structure with minimal ventilation rates to ensure the moisture is ventilated to outside. Internal surface temperatures are likely to be even lower than space temperatures, especially in winter. The combination of this fact and that moisture generated by occupation may aggravate conditions, further underlines the importance of ventilating moisture sources to outside.

Whilst the positive differences in conditions provided by the innovative structure are statistically significant they are still small and might be unlikely to be financially beneficial in the short term. Work is underway with the detailed monitoring of temperature and humidity in each layer of the wall construction of each building. This will enable tracking in detail of the passage of vapour throughthe envelope and the identification of interstitial condensation risk and help allocate the differences to the performance of the internal vapour check and the plywood rigid air barrier. Further work will include monitoring conditions under controlled, active heating, cooling and moisture generation which should provide a stiffer test and opportunity for the structure to show a financially beneficial difference.

\section{Acknowledgments}

This research has been carried out with the support of Thomas van Raamsdonk of ProClima and the Unitec Internal Research Fund.

\section{Author Contributions}

Roger Birchmore contributed to the research design and carried out the collection and analysis of the data. Robert Tait and Andy Pivac contributed to the research design experimentation set up and conducting measurements.

\section{Conflicts of Interest}

The authors declare no conflict of interest.

\section{References}

1. Mackintosh, L. NIWA Overview of New Zealand Climate. 2001. Available online: https://www.niwa.co.nz/education-and-training/schools/resources/climate/overview (accessed on 11 June 2014).

2. BizEE Degree Days. Weather Data for Energy Professionals. Available online: http://www.degreedays.net/\# (accessed on 22 December 2014).

3. De Groot, H. Indoor Air Quality and Health. An Analysis of the Indoor Air Quality and Health in New Zealand's Homes. 2009. Available online: http://www.archigraphic.de/_originals/pdfs/ indoor_air_quality_and_health.pdf (accessed on 11 June 2014). 
4. Howden-Chapman, P.; Saville-Smith, K.; Crane, J.; Wilson, N. Risk factors for mould in housing: A national survey. Indoor Air 2005, 15, 469-476.

5. Howden-Chapman, P.; Crane, J.; Chapman, R.; Fougere, G. Improving health and energy efficiency through community-based housing interventions. Int. J. Public Health 2011, 56, 583-588.

6. New Zealand Business Council for Sustainable Development (NZBCSD). Media Release: \$20 Billion Cost of Fixing Country's Homes Less than 4\% of Their Value. 2008. Available online: http://www.scoop.co.nz/stories/BU0812/S00020.htm (accessed on 11 June 2014).

7. World Health Organisation. Guidelines for Indoor Air Quality: Dampness and Mould. 2009. Available online: http://site.ebrary.com/lib/unitech/Doc?id=10367463\&ppg=55 (accessed on 11 June 2014).

8. Sargent, S. Getting Clear on Vapour Barriers and Underlays. 2007, Build 99. Available online: http://www.buildmagazine.org.nz/articles/show/getting-clear-on-vapour-barriers-and-underlays/ (accessed on 4 February 2015).

9. Howden-Chapman, P.; Matheson, A.; Crane, J.; Viggers, H.; Cunningham, M.; Blakely, T.; Cunningham, C.; Woodward, A.; Saville-Smith, K.; O'Dea, D.; et al. Effects of insulating existing houses on health inequality: Cluster randomised study in the community. Br. Med. J. 2007, 334, 460.

10. Easton, L.; Saville Smith, K. Homesmart Renovations-Testing Tools to Promote Sustainable Renovation. In Proceedings of the New Zealand Sustainable Building Conference, Wellington, New Zealand, 26-28 May 2010.

11. Callau, M. Upgrading Housing in NZ for Thermal Efficiency. In Proceedings of the New Zealand Sustainable Building Conference, Wellington, New Zealand, 26-28 May 2010.

12. Burgess, J.C.; Buckett, N.R.; Camilleri, M.J.T.; Burrough, L.J.; Pollard, A.R. Papakowhai Retrofit Project-Improving the Thermal Envelope and Space Heating. In Proceedings of the New Zealand Sustainable Building Conference, Wellington, New Zealand, 26-28 May 2010.

13. Su, B. Prevention of inter mould growth in housing. Archit. Sci. Rev. 2006. 49, 385-390.

14. Su, B. Indoor moisture control of Auckland houses with different ventilation systems. Int. J. Civ. Archit. Sci. Eng. 2013, 7, 411-415.

15. Leardini, P.M.; van Raamsdonk, T. Design for Airtightness and Moisture Control in New Zealand Housing. In Proceedings of the New Zealand Sustainable Building Conference, Wellington, New Zealand, 26-28 May 2010.

16. WUFI Pro, 2D, Plus Software 2013. Fraunhofer-Institute fur Bauphysik (IBP), Holzkirchen. Available online: http://www.wufi.de/index_e.html (accessed on 21 January 2015).

17. De Groot, H.; Leardini, P.M. Indoor Air Quality and Health in New Zealand's Traditional Homes. In Proceedings of the 44th Annual Conference of the Architectural Science Association, Unitec Institute of Technology, Auckland, New Zealand, 24-26 November 2010.

18. Love, J. Mapping the Impact of Changes in Occupant Heating Behaviour on Space Heating Energy Use as a Result of UK Domestic Retrofit. Retrofit Conference, University of Salford, UK, 2012. Available online: http://www.salford.ac.uk/_data/assets/pdf_file/0005/142385/023-Love.pdf (accessed on 21 January 2015). 
19. Clevenger, C.M.; Haymaker, J. The Impact of Building Occupation on Energy Modelling Simulations, Joint International Conference on Computing and Decision Making in Civil and Building Engineering, Montreal, Canada, 2006. Available online: http://web.stanford.edu/group/peec/cgi-bin/docs/people/ profiles/The $\% 20$ Impact $\% 20$ of $\% 20$ the $\% 20$ Building\%20Occupant $\% 20$ On $\% 20$ Energy $\% 20$ Modelin g\%20Simulations.pdf (accessed on 21 January 2015).

20. Department of Building and Housing Compliance document for New Zealand Building Code Clause H1 Energy Efficiency-Third Edition. Available online: http:/www.dbh.govt.nz/UserFiles/File/ Publications/Building/Compliance-documents/H1-energy-efficiency-3rd-edition-amendment-2.pdf (accessed on 21 January 2015).

21. Specification for Preservative Treatment Part 3: Plywood; SNZ 2012 AS/NZ 1604.3; Standards New Zealand: Wellington, New Zealand, 2012.

22. Plywood-Structural Part 0: Specifications; SNZ, 2012b, AS/NZS 2269.0:2012; Standards New Zealand: Wellington, New Zealand, 2012.

23. Moll, L.; van Raamsdonk, T. A New Zealand Based Study on Airtightness and Moisture Management; ProClima, NZ Ltd: Wellington, New Zealand, 2009.

24. Barley, D.; Deru, M.; Pless, S.; Orcellini, P. Procedure for Measuring and Reporting Commercial Building Energy Performance; Technical Report NREL/TP-550-38601; National Renewable Energy Laboratory, Battelle: Golden, CO, USA, 2005.

25. LASCAR Certificate of Calibration. Available online: http://www.lascarelectronics.com/ pdf-usb-datalogging/data-logger0237687001331303304.pdf (accessed on 21 January 2015).

26. Thermal Performance of Buildings-Determination of Air Permeability of Buildings-Fan Pressurization Method; European Committee for Standardization CEN/TC 89 2000. EN 13829:2000; British Standards Institution: London, UK, 2001.

27. Stoecklein, A.; Bassett, M. ALF3-A Design Tool for Energy Efficient Houses; Building Research Association of New Zealand: Judgeford, New Zealand, 1999.

28. Passive House Institute Passive House Requirements. Available online: http://www.passiv.de/en/ 02_informations/02_passive-house-requirements/02_passive-house-requirements.htm (accessed on 11 June 2014).

29. TenWolde, A.; Pilon, C. The Effect of Indoor Humidity on Water Vapor Release in Homes. Available online: http://web.ornl.gov/sci/buildings/2012/2007\%20B10\%20papers/071_TenWolde.pdf (accessed on 11 June 2014).

30. Mitamura, T.; Rode, C.; Schultz, J. Full-Scale Testing of Indoor Humidity and Moisture Buffering in Building Materials. In Proceedings of the Indoor Air Quality 2001, Moisture, Microbes, and Health Effects: Indoor Air Quality and Moisture in Buildings, ASHRAE: Atlanta, GA, USA, 2001.

(C) 2015 by the authors; licensee MDPI, Basel, Switzerland. This article is an open access article distributed under the terms and conditions of the Creative Commons Attribution license (http://creativecommons.org/licenses/by/4.0/). 